\title{
Ordforklaringer
}

Preeklampsi (svangerskapsforgiftning): Karakterisert ved hypertensjon og proteinuri som utvikles etter 20 . svangerskapsuke. Det er en av de viktigste årsakene til sykdom og død hos gravide kvinner i den vestlige verden. I Norge får omtrent $3 \%$ av alle gravide preeklampsi, og det er vanskelig å forutsi hvem som er i risikogruppen. Etiologien er multifaktoriell.

Decidua: Utgjør den maternelle delen av placenta og dannes fra endometriet som en respons på graviditet. Spiralarteriene, som forsyner placenta med oksygenert blod, strekker seg fra myometriet og gjennom decidua. For å sikre tilstrekkelig blodstrøm moduleres disse av ekstravilløse trofoblaster som invaderer decidua. Decidua representerer derfor en møtesone mellom morens og fosterets celler.

\section{Gener og reaksjonsveier knyttet til preeklampsi}

\author{
Kvinner med preeklampsi har en annen genetisk profil enn andre \\ kvinner, ifølge forskning utført av forskerlinjestudenter i Trondheim.
}

Preeklampsi er en av de viktigste årsakene til sykdom og død hos gravide i den vestlige verden. Både immunologiske og genetiske faktorer er involvert, sannsynligvis gjennom et samspill mellom placenta og kvinnekroppen. Redusert blodgjennomstrømming i placenta står sentralt i sykdomsutviklingen. Prosesser i decidua, som er den maternelle delen av placenta og utgjør møtesonen mellom mor og foster, kan være avgjørende.

Decidualt vev fra 37 kvinner med preeklampsi og 58 kvinner med ukompliserte svangerskap ble samlet inn ved St. Olavs hospital og Haukeland universitetssykehus for å finne «genetiske signaturer» av sykdom i vevet. RNA ble isolert, og en helgenomstranskripsjonsstudie med mer enn 48000 transkripter fra alle kjente gener ble gjennomført.

- Vi fant at 455 transkripter var ulikt uttrykt hos kvinner med preeklampsi sammenliknet med de andre kvinnene. Disse transkriptene omfattet både nye kandidatgener, for eksempel ARL5B og SLITRK4, og gener som tidligere var assosiert med preeklampsi, for eksempel $P L A 2 G 7 \mathrm{og}$ $H M O X 1$, sier førsteforfatterne Mari Løset og Siv Boon Mundal ved Norges teknisknaturvitenskapelige universitet.

- Vi gjorde deretter nettverksanalyser for å se om de ulikt uttrykte genene påvirket hverandre. Vi fant sju signifikante reaksjonsveier som var assosiert med preeklampsi. Dette kan gi en pekepinn om patogenesen for preeklampsi. Blant annet så vi at gener som er involvert i stress i endoplas- matisk retikulum og immunologiske reaksjonsveier var overrepresentert, sier de.

- Vi ønsker å følge opp disse funnene med funksjonelle analyser, forteller Løset. - Forskerguppen er i gang med å undersøke om det er forskjeller i proteinnivå for enkelte av reaksjonsveiene. Håpet er at økt innsikt i patofysiologien bak preeklampsi på sikt kan gi nye terapeutiske muligheter, sier Løset og Mundal.

\section{Forskning på preeklampsi}

Førsteforfatterne Mari Løset og Siv Boon Mundal er forskerlinjestudenter ved Norges teknisk-naturvitenskapelige universitet. De er en del av reproduksjonsgruppen ved Institutt for kreftforskning og molekylærmedisin, som ledes av professor Rigmor Austgulen. Artikkelen er basert på et samarbeid mellom forskere ved reproduksjonsgruppen i Trondheim, Kvinneklinikken ved Haukeland universitetssykehus og Southwest Foundation for Biomedical Research, San Antonio, Texas, der Løset og Mundal tilbrakte et forskerlinjesemester i 2008.

\section{Erlend Hem}

erlend.hem@medisin.uio.no

Tidsskriftet

\section{Litteratur}

1. Løset M, Mundal SB, Johnson MP et al. A transcriptional profile of the decidua in preeclampsia. Am J Obstet Gynecol 2010; 203. E-publisert 8.10.2010.
Helgenomstranskripsjonsstudie: Transkripsjon er prosessen hvor DNA oversettes til RNA. RNA-biten kalles et transkript. I en helgenomstranskripsjonsstudie undersøkes tilstedeværelsen av transkripter tilhørende så godt som alle gener i genomet, med alle tenkelige spleisevarianter. I tillegg kan man undersøke tilstedeværelsen av hypotetiske transkripter.

Genetisk reaksjonsvei: Utgjør en gruppe gener som interagerer med hverandre. De ulike genene er avhengig av hverandres individuelle funksjon og aktivitet. Summen av deres interaksjon med hverandre fører til en utført funksjon i cellen.

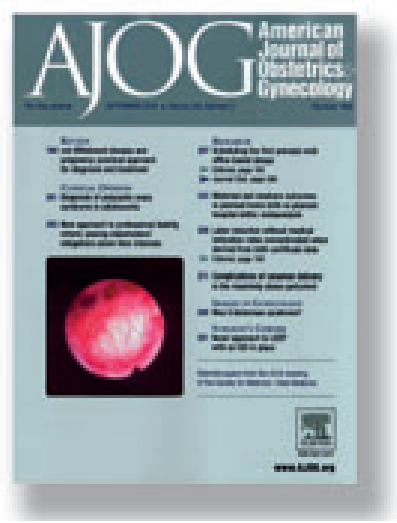

Artikkelen ble e-publisert 8.10. 2010 i det velrenommerte tidsskriftet American Journal of Obstetrics and Gynecology (www.ajog.org)

\section{Tips oss}

Er du iferd med å publisere eller har du nylig publisert eller har du nylig publisert Send tips til erlend.hem@medisin.uio.no 